\title{
Molecular species identification of Central European ground beetles (Coleoptera: Carabidae) using nuclear rDNA expansion segments and DNA barcodes
}

\author{
Michael J Raupach ${ }^{1,2^{*}}$, Jonas J Astrin ${ }^{1}$, Karsten Hannig ${ }^{3}$, Marcell K Peters ${ }^{1}$, Mark Y Stoeckle ${ }^{4}$, \\ Johann-Wolfgang Wägele
}

\begin{abstract}
Background: The identification of vast numbers of unknown organisms using DNA sequences becomes more and more important in ecological and biodiversity studies. In this context, a fragment of the mitochondrial cytochrome c oxidase I (COI) gene has been proposed as standard DNA barcoding marker for the identification of organisms. Limitations of the COI barcoding approach can arise from its single-locus identification system, the effect of introgression events, incomplete lineage sorting, numts, heteroplasmy and maternal inheritance of intracellular endosymbionts. Consequently, the analysis of a supplementary nuclear marker system could be advantageous.

Results: We tested the effectiveness of the COI barcoding region and of three nuclear ribosomal expansion segments in discriminating ground beetles of Central Europe, a diverse and well-studied invertebrate taxon. As nuclear markers we determined the 185 rDNA: V4, 18S rDNA: V7 and 28S rDNA: D3 expansion segments for 344 specimens of 75 species. Seventy-three species (97\%) of the analysed species could be accurately identified using COI, while the combined approach of all three nuclear markers provided resolution among 71 (95\%) of the studied Carabidae.

Conclusion: Our results confirm that the analysed nuclear ribosomal expansion segments in combination constitute a valuable and efficient supplement for classical DNA barcoding to avoid potential pitfalls when only mitochondrial data are being used. We also demonstrate the high potential of $\mathrm{CO}$ barcodes for the identification of even closely related carabid species.
\end{abstract}

\section{Background}

In times of climate change and massive habitat destruction, the reliable identification of species represents a pivotal component for biodiversity studies and conservation planning. However, routine identification of many species can be difficult and time-consuming, often requiring highly specialized knowledge, and therefore represents a limiting factor in biodiversity assessments and ecological studies [1-3]. In addition to this, the identification of larval stages or fragments of organisms

\footnotetext{
* Correspondence: m.raupach.zfmk@uni-bonn.de

'Zoologisches Forschungsmuseum Alexander Koenig, Adenauerallee 160162, 53113 Bonn, Germany

Full list of author information is available at the end of the article
}

using conventional morphological methods constitutes an impossible task for many taxa [4-6].

In this context, the use of DNA sequences represents a promising and effective tool for fast and accurate species identification [7-9]. Animal mitochondrial DNA exhibits several characteristics that makes it attractive for molecular taxonomy, namely the generally high substitution rates, the almost exclusively maternal inheritance, and the lack of recombination [10,11]. Moreover, because of uniparental inheritance and haploidy, mtDNA has a four-fold smaller effective population size compared to nuclear DNA, leading to faster lineage sorting [12]. A 650 base pair fragment of the $5^{\prime}$ end of the mitochondrial cytochrome $c$ oxidase I (COI) gene was proposed as global standard, the so-called "barcode

\section{Ciomed Central}


region" for animals $[7,13]$. This barcode approach has been successfully applied in various vertebrate and invertebrate taxa for species delimitation and identification [14-19]. Subsets of the standard COI barcode have been shown to be effective for species-level identification in specimens whose DNA is degraded [20,21]. Nevertheless, the exclusive use of mitochondrial gene fragments is not without risks. The concept of DNA barcoding relies on low levels of mtDNA variation within species in combination with clear genetic differentiation between species, the so-called barcoding gap. Various studies found high levels of overlap in intraand interspecific genetic distances for some selected taxa [22,23]. DNA barcoding can also overestimate the number of species when nuclear mitochondrial pseudogenes (numts) are coamplified [24-27]. Introgression events and/or incomplete lineage sorting can cause trans-specific polymorphisms in mitochondrial DNA, contorting the mitochondrial variability of studied organisms [28]. Such events have been demonstrated for various arthropod taxa, for example insects [29-33] or spiders $[34,35]$. Heteroplasmy events can also confuse the identification system also [36], but are rare [37]. Finally, maternally inherited endosymbionts such as the $\alpha$-proteobacteriae Wolbachia or Rickettsia may cause linkage disequilibrium with mtDNA, resulting in a homogenization of mtDNA haplotypes [38-40].

All these problems show that standardised and complementing nuclear markers are necessary if a provisional species, uncovered using COI barcodes, is to be considered as species. In this context, nuclear ribosomal genes may represent potential supplementary markers for species identification. Nuclear ribosomal genes are generally considered to be highly conserved, but are actually composed of a mixture of conserved and variable regions that are organized in clusters that contain hundreds of copies per haploid genome. In metazoan taxa, these tandem rDNA units are highly uniform within a species [41-44], but differ between closely related species [e.g. [45-49]]. Until now, there have only been a few studies using nuclear rDNA sequences for DNA taxonomy: complete small ribosomal subunit DNA (18S rDNA) sequences were used to identify invertebrate taxa $[1,5]$, while the variable D1-D2 or D3D5 regions of the large ribosomal subunit DNA (28S rDNA) were found to be suitable markers for various fungi $[50,51]$, arthropods $[2,52,53]$ freshwater meiobenthic communities [54], and a broad range of metazoan taxa [55]. The main limitation to these approaches lies in the length of the analysed sequences (usually >>1000 base pairs (bp)), preventing a simple amplification of degraded DNA (e.g. from collection specimens in museums) and, most important, efficient use in large-scale biodiversity studies [56]. Nevertheless, it should be also noted that various potential problems can be associated with the use of ribosomal genes, for example intragenomic variations among rRNA gene copies. As far as we know, very few cases of intragenomic variations have been observed for Metazoa until now [57-63]. Multiple variants of the $18 \mathrm{~S}$ rRNA gene were found in a dinoflagellate [64], a platyhelminth [65], and the Lake sturgeon Acipenser fulvescens [66,67].

While core elements of the eukaryotic ribosomal RNA genes are considered to be essential for ribosome functions that evolve slowly and evenly $[68,69]$, the so-called divergence or expansion segments show a high variability in primary sequence and length between even closely related species as a consequence of DNA slippage-like processes [70-73]. In most cases, expansion segments have highly conserved flanking sites $[68,69,74]$. Although the exact functions remain elusive, various studies of eukaryotic ribosomes provide some clues about the functional aspects of expansion segments in rRNAs [75-77], including intersubunit bridges and scaffolds allowing proteins to bind to ribosomes [78]. In addition, some of their structural features seem to be important for the stability of rRNA $[75,79,80]$.

Following these considerations, we analysed and compared the usefulness of nuclear ribosomal expansion segments and COI barcodes for the molecular identification of Central European carabid beetles. The Carabidae are among the largest and most diverse insect families, with no less than an estimated 40,000 described species that inhabit all terrestrial habitat types from the sub-arctic to wet tropical regions $[81,82]$. This diversity and wide distribution, along with the predominance of these beetles in a large variety of habitats, has resulted in a considerable interest in many aspects of their biology, including systematics, phylogeny, biogeography, ecology and evolution [83-87]. Ground beetles show different levels of habitat selectivity, ranging from generalists to specialists, and therefore carabid assemblages can be used as highly valuable bioindicators for characterizing disturbances in various habitats such as forests, meadows or fens [88]. Due to the continuous and intensive study of ground beetles in Central Europe, their taxonomic classification is wellestablished. In Central Europe, more than 750 species are known [89]. Nevertheless, the identification of many species and especially of larval stages can be very difficult as a consequence of high morphological variability within species and due to the existence of sibling species.

Our study examined the effectiveness and suitability of one mitochondrial (COI) and three nuclear markers, the expansion segments V4 and V7 of the $18 \mathrm{~S}$ rDNA and the D3 expansion segment of the 28S rDNA as molecular identification tools for 75 selected ground beetle species out of 26 genera from Central Europe. We compared intra- and interspecific divergences using Kimura 
2-parameter (K2P) distances and uncorrected $p$-distances between all analysed COI sequences and $p$-distances for all rDNA gene fragments of many closely related species, e.g. Agonum emarginatum/viduum, Clivina collaris/fossor, or Harpalus affinis/rubripes. Furthermore, we analysed the discrimination capacity of the used marker systems within two well-known pairs of sibling species, Bembidion lampros/properans [90-94] and Pterostichus nigrita/rhaeticus [95-98].

\section{Results}

We examined 344 specimens representing 75 species and 28 genera of Central European ground beetles. The mitochondrial COI region and all three selected nuclear regions were successfully amplified and sequenced in all cases, confirming the universality of the selected primers for ground beetles. While the majority of the analysed beetles had been collected 1-2 years ago and were preserved in $96 \%$ ethanol, it was also possible to generate full length sequences with tissue samples of pinned specimens up to 12 years old. There was no indication of numt amplification for the COI dataset. Most importantly, we found no intragenomic or intraspecific variations within the analysed nuclear rDNA markers.

\section{The COI dataset}

All COI sequences were heavily AT biased, with an average $\mathrm{A}+\mathrm{T}$-content of $67.6 \%$. The average interspecific K2P distance was $12.6 \%$ ( $p$-distance: $11.5 \%$ ), while the lowest distances were observed between Agonum emarginatum and Agonum viduum (K2P distances: 3.14\%, p-distances: $3.06 \%$ ) (Figure 1). Intraspecific distances ranged up to $3.8 \%$ for the analysed Nebria hellwigii specimens ( $p$-distances: up to 3.7\%), while specimens of Carabus nemoralis were characterized by K2P distances ranging up to 2.7\% ( $p$-distances: 2.6\%) (Figure 2). However, both species revealed two distinct clades without intermediate haplotypes. In contrast to this, it was not possible to discriminate Pterostichus nigrita from Pterostichus rhaeticus using COI sequences. Both species shared various identical haplotypes, and K2P distances ranged from 0 up to $0.5 \%$ ( $p$-distances: 0 to $0.5 \%$ ) for both species (Figure 2,

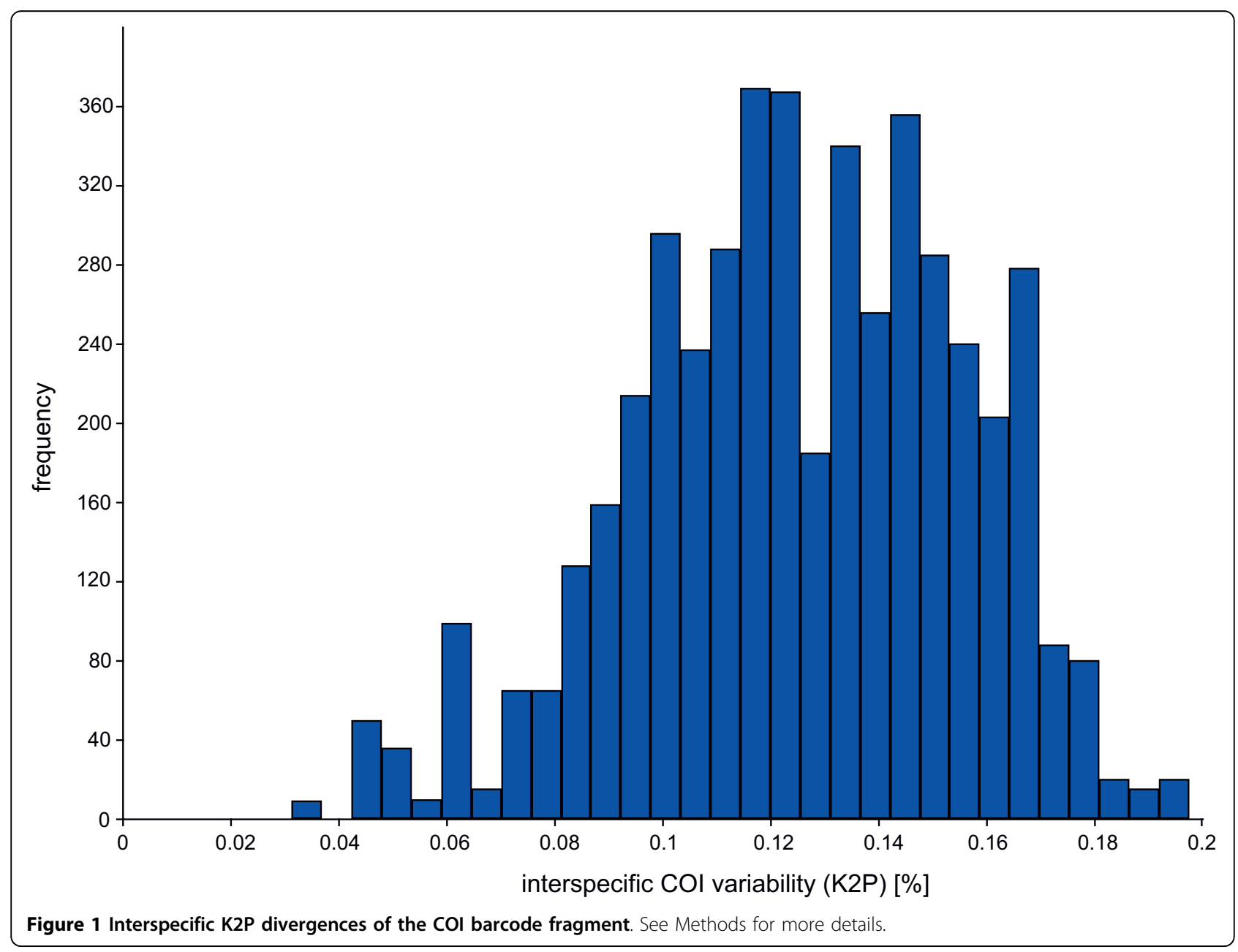




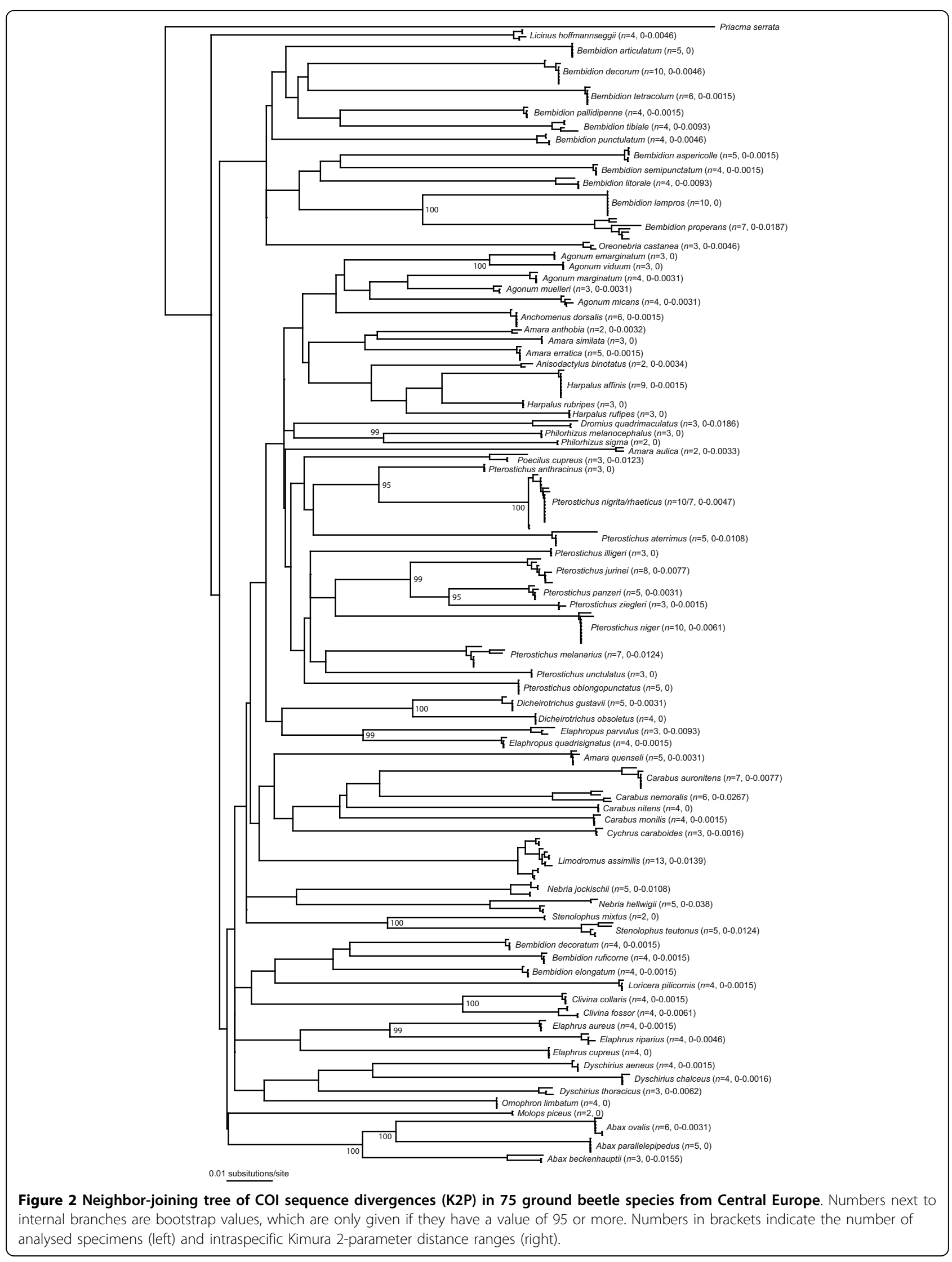


Table 1). A Klee diagram revealed correlation values > 0.75 for six species pairs, Agonum emarginatum/viduum, Agonum marginatum/muelleri, Clivina collaris/fossor, Harpalus affinis/rubripes, Pterostichus nigrita/rhaeticus, and Pterostichus panzeri/ziegleri, indicating a high similarity of the uncorrected COI sequences among these species pairs (Figure 3).

\section{The rDNA datasets}

Fragment lengths ranged from 185 (various species) to 254 bp (Molops piceus) with an average length of 198 bp for the D3 marker, 355 (Dromius quadrimaculatus) to 515 bp (Omophron limbatum) for the V4 marker (average length: $384 \mathrm{bp}$ ), and 388 (both studied
Philorhizus species) to $504 \mathrm{bp}$ (Omophron limbatum) for the V7 marker (average length: $414 \mathrm{bp}$ ) (Figure 4). Average $p$-distances between species within genera were $6.0 \%$ for the D3, 3.7\% for the V4 and $4.6 \%$ for the V7 expansion fragment (Figure 5). Our study revealed that single base changes (substitutions, insertions or deletions) for all three analysed markers unambiguously separate closely related species, e.g. Amara anthobia and Amara erratica (D3), Agonum viduum and Agonum marginatum (V4), and Harpalus affinis and Harpalus rubripes (V7) (Table 1). Nevertheless, in some cases various species showed identical sequences and therefore no resolution, anticipating a successful species discrimination, e.g. Elaphropus parvulus and Elaphropus

Table 1 Interspecific nucleotide divergences of all four markers, given in cases in which at least one of the analysed markers did not resolve the species pair

\begin{tabular}{|c|c|c|c|c|c|}
\hline Taxa pairs & 28S: D3 & 18S: V4 & 18S: V7 & $\begin{array}{c}\text { 28S: D3 +18S: V4 } \\
+ \text { V7 }\end{array}$ & $\mathrm{COI}$ \\
\hline Agonum emarginatu/viduum & $\begin{array}{l}\text { identical } \\
\text { sequences }\end{array}$ & $0.0026 / 1$ & $0.0025 / 1$ & $0.002 / 2$ & 0.0314 \\
\hline Agonum marginatum/micans & $0.005 / 1$ & $\begin{array}{l}\text { identical } \\
\text { sequences }\end{array}$ & $0.0025 / 1$ & $0.0021 / 2$ & $0.0793-0.0828$ \\
\hline Agonum marginatum/muelleri & $0.005 / 1$ & $\begin{array}{l}\text { identical } \\
\text { sequences }\end{array}$ & $0.0025 / 1$ & $0.0021 / 2$ & $0.0506-0.0507$ \\
\hline Agonum micans/muelleri & $0.005 / 1$ & $\begin{array}{l}\text { identical } \\
\text { sequences }\end{array}$ & $\begin{array}{l}\text { identical } \\
\text { sequences }\end{array}$ & $0.001 / 1$ & $0.0809-0.0861$ \\
\hline Amara anthobia/erratica & $0.005 / 1$ & $0.0028 / 1$ & $\begin{array}{l}\text { identical } \\
\text { sequences }\end{array}$ & $0.0021 / 2$ & $0.0677-0.0713$ \\
\hline Amara anthobia/similata & $\begin{array}{l}\text { identical } \\
\text { sequences }\end{array}$ & $0.0084 / 3$ & $0.0274 / 11$ & $0.0146 / 14$ & $0.0713-0.0714$ \\
\hline $\begin{array}{l}\text { Anisodactylus binotatus/Harpalus } \\
\text { rubripes }\end{array}$ & $0.0302 / 6$ & $\begin{array}{l}\text { identical } \\
\text { sequences }\end{array}$ & $0.005 / 2$ & $0.0084 / 8$ & $0.0723-0.0744$ \\
\hline Bembidion decorum/tetracolum & $\begin{array}{l}\text { identical } \\
\text { sequences }\end{array}$ & $0.0048 / 2$ & $0.0145 / 6$ & $0.0079 / 8$ & $0.1245-0.1283$ \\
\hline Clivina collaris/fossor & $\begin{array}{l}\text { identical } \\
\text { sequences }\end{array}$ & $\begin{array}{l}\text { identical } \\
\text { sequences }\end{array}$ & $\begin{array}{l}\text { identical } \\
\text { sequences }\end{array}$ & identical sequences & $0.0446-0.0503$ \\
\hline Dyschirius aeneus/thoracicus & $0.0313 / 6$ & $\begin{array}{l}\text { identical } \\
\text { sequences }\end{array}$ & $0.0119 / 5$ & $0.0109 / 11$ & $0.109-0.1126$ \\
\hline Elaphropus parvulus/quadrisignatus & $\begin{array}{l}\text { identical } \\
\text { sequences }\end{array}$ & $\begin{array}{l}\text { identical } \\
\text { sequences }\end{array}$ & $0.0075 / 3$ & $0.003 / 3$ & $0.0739-0.079$ \\
\hline Harpalus affinis/rubripes & $\begin{array}{l}\text { identical } \\
\text { sequences }\end{array}$ & $0.0028 / 1$ & $0.0025 / 1$ & $0.0021 / 2$ & 0.0458 \\
\hline Harpalus affinis/rufipes & $0.02 / 4$ & $\begin{array}{l}\text { identical } \\
\text { sequences }\end{array}$ & $0.0025 / 1$ & $0.0052 / 5$ & $0.0706-0.0723$ \\
\hline Nebria hellwigii & $\begin{array}{l}\text { identical } \\
\text { sequences }\end{array}$ & $\begin{array}{l}\text { identical } \\
\text { sequences }\end{array}$ & $0.0024 / 1$ & $0.001 / 1$ & $0-0.038$ \\
\hline Pterostichus jurinei/ziegleri & $0.042 / 9$ & $\begin{array}{l}\text { identical } \\
\text { sequences }\end{array}$ & $0.0125 / 5$ & $0.0143 / 14$ & $0.0573-0.064$ \\
\hline Pterostichus nigrita/rhaeticus & $\begin{array}{l}\text { identical } \\
\text { sequences }\end{array}$ & $\begin{array}{l}\text { identical } \\
\text { sequences }\end{array}$ & $\begin{array}{l}\text { identical } \\
\text { sequences }\end{array}$ & identical sequences & $\begin{array}{l}\text { identical } \\
\text { sequences }\end{array}$ \\
\hline Pterostichus panzeri/jurinei & $0.0467 / 10$ & $\begin{array}{l}\text { identical } \\
\text { sequences }\end{array}$ & $0.0125 / 5$ & $0.0153 / 15$ & $0.0572-0.0657$ \\
\hline Pterostichus panzeri/ziegleri & $0.014 / 3$ & $\begin{array}{l}\text { identical } \\
\text { sequences }\end{array}$ & $\begin{array}{l}\text { identical } \\
\text { sequences }\end{array}$ & $0.0031 / 3$ & $0.0442-0.0475$ \\
\hline Stenolophus mixtus/teutonus & $\begin{array}{l}\text { identical } \\
\text { sequences }\end{array}$ & $0.0111 / 4$ & $0.005 / 2$ & $0.0062 / 6$ & $0.0865-0.0886$ \\
\hline
\end{tabular}

For COI sequences, values indicate the range of K2P divergences. For the nuclear markers, values indicate $p$-distances (left) and the number of base substitutions (right). 


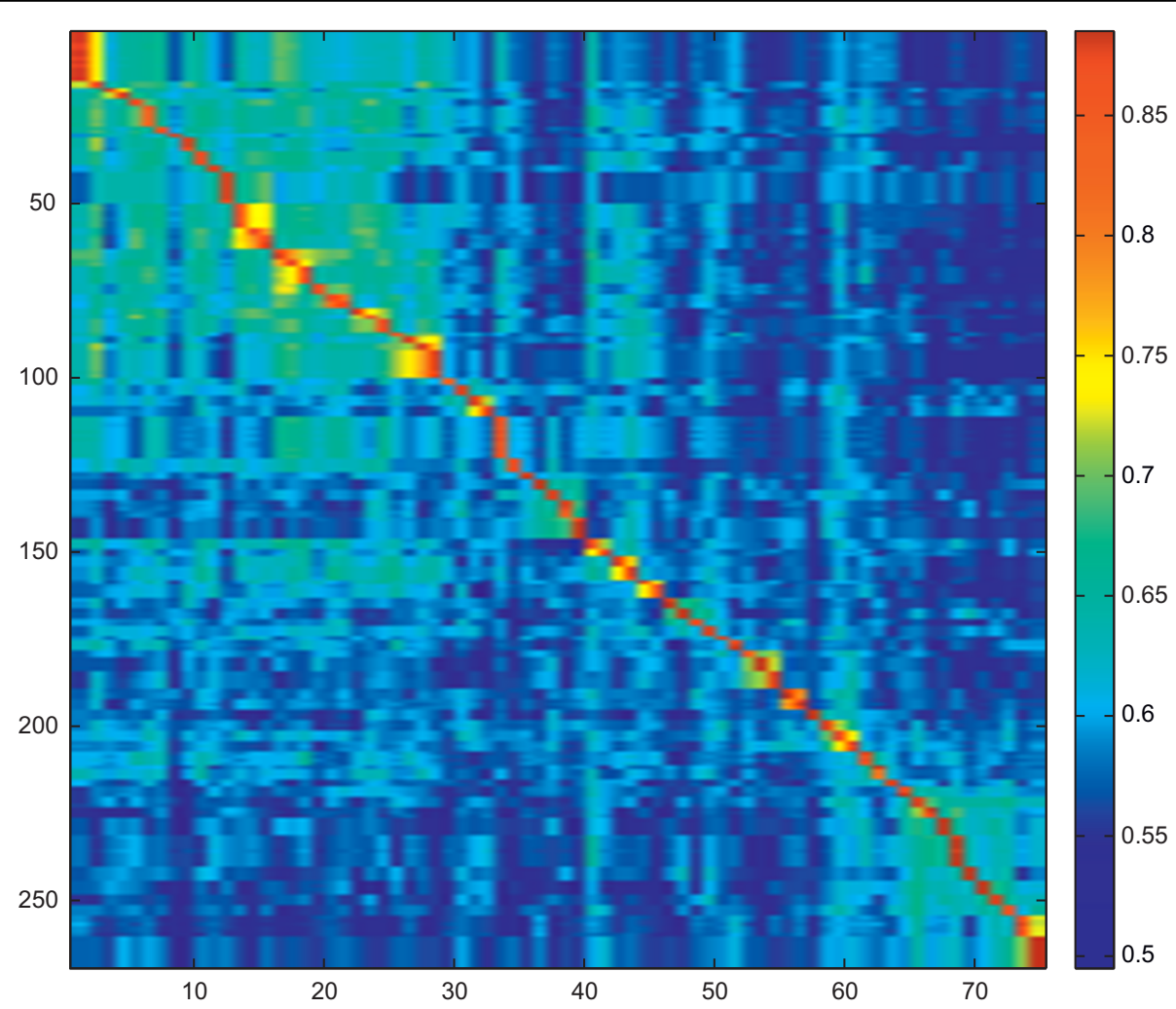

Figure 3 Indicator vector correlations of the COI data set (Klee diagram). The false-color representation depicts correlations among $269 \mathrm{COI}$ test sequences (y-axis) and 75 species-level indicator vectors (x-axis). In total, 263 (97.7\%) of the test sequences showed highest correlation with their respective species indicator vector; exceptions were mis-assignments of Pterostichus nigrita and Pterostichus rhaeticus, which share predominant identical COI haplotypes.

quadrisignatus for the D3 (Additional file 1), Agonum marginatum, Agonum micans and Agonum muelleri for the V4 (Additional file 2), and Amara anthobia and Amara erratica for the V7 marker (Additional file 3). All taxa without resolution are summarized in Table 1. In the case of both Clivina species and the sibling species Pterostichus nigrita/rhaeticus, no substitutions were observed in the studied nuclear sequences at all. Otherwise, it was possible to discriminate two different V7 sequences for Nebria hellwigii, differing in one base. Furthermore, both sequences correlated with the two distinct COI haplotype clusters (see above), while the two other nuclear markers showed no variation. Summarizing the results, it was possible to discriminate 61 (81\%) species using the D3 marker, 57 (76\%) using the V4 marker, and 65 (87\%) using the V7 marker. The combined analyses of all three nuclear markers provided resolution for 71 (95\%) species (Figure 6).

\section{Discussion}

The issue of choosing thresholds for species delineation is a primary concern for molecular taxonomy [99], particularly when intraspecific variation can be shown to be greater than interspecific variation. In the case of COI, a species identification threshold has been suggested that amounts to ten times the arithmetic mean of intraspecific distances [100], which is usually low (less than 1\%) and rarely more than $2 \%$ across a broad range of taxa [7,13,20,100-104]. However, this "10-fold rule" has been questioned in subsequent studies [105-107], because it has no strong biological background and undoubtedly cannot become a universal, invariable criterion to species delineation across all taxa [24,25,107]. Another approach comprises the analysis of mtDNA branching times using a general mixed Yule-coalescent (GMYC) model estimates the species boundary by identifying independently evolving lineages as a transition from coalescent to speciation branching patterns on a phylogenetic tree [108]. First case studies reveal the potential of this approach [108-111], but former bottleneck events or selective sweeps can become problematic in reconstructing the coalescence of mtDNA lineages and therefore for species delineation. It should be also kept in mind that such methods are also sensitive to introgression and incomplete lineage sorting, and cannot be used analyzing a high number of specimens. 


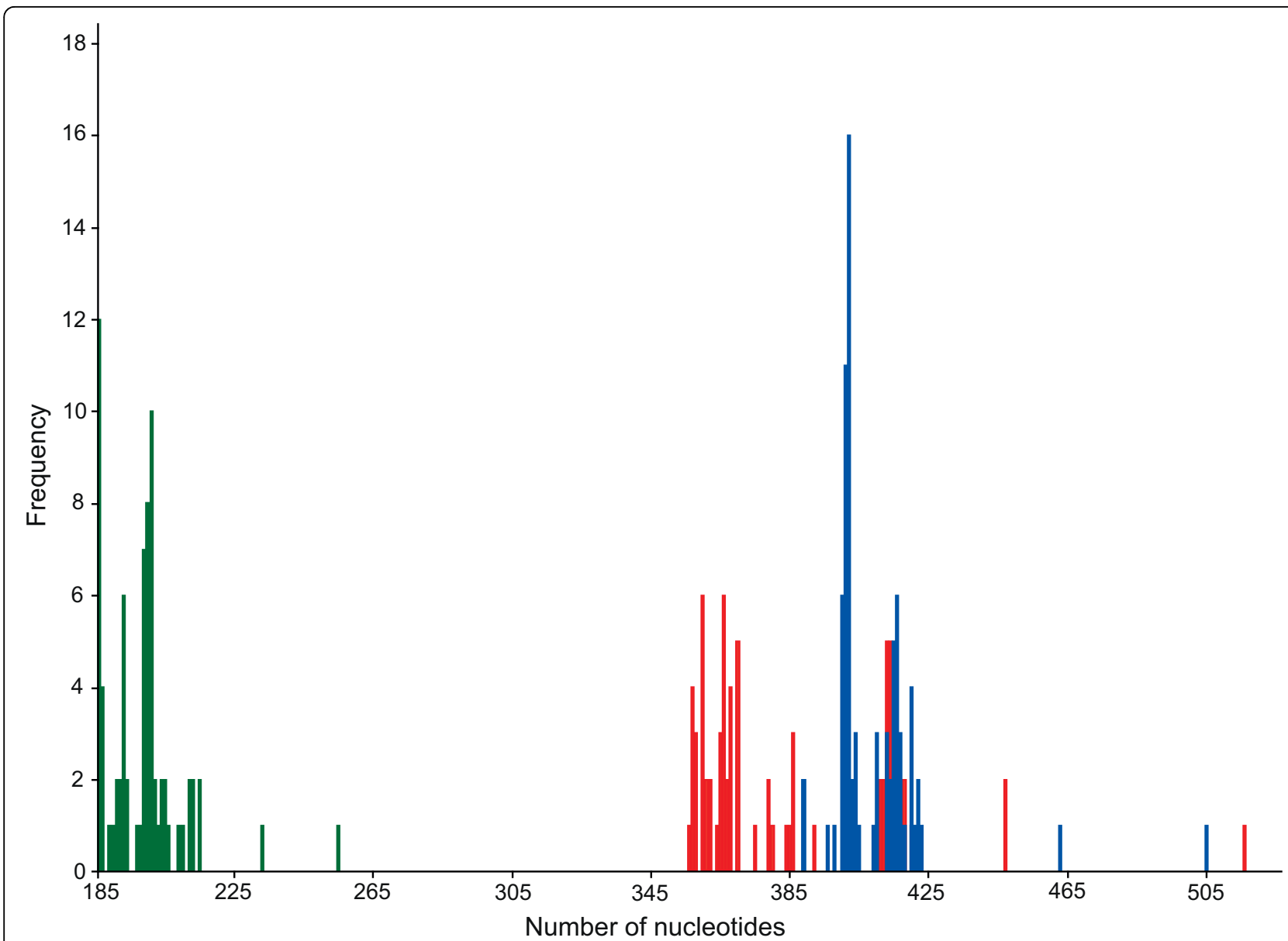

Figure 4 Histogram of fragment length frequencies of the analysed V4 (red), V7 (blue) and D3 (green) sequences. Fragment lengths from 185 to $254 \mathrm{bp}$ for the D3 marker, 355 to $515 \mathrm{bp}$ for the V4 marker, and 388 to $504 \mathrm{bp}$ for the V7 marker.

Based on our data, lowest interspecific COI distances were observed between Agonum emarginatum and Agonum viduum (K2P distances: $3.14 \%$, p-distances: $3.06 \%$ ). With one exception (Nebria hellwigii), all intraspecific distances were below these values. Our results confirm the high potential of COI barcodes for species identification of even closely related carabid species although it was not possible to discriminate the two species of the Pterostichus nigrita/rhaeticus species complex (Figure 2, Figure 3, Table 1). Nevertheless, it is important to study additional specimens of the already analysed species, preferable from different locations, as well as missing species have to be analysed to gain more specific insights in the intra- and interspecific COI variability of ground beetles.

For molecular species identification, the use of rDNA is not a new approach [1,2,5,50-55]. However, published studies rely on the analysis of long rDNA fragments [2,50-55] or complete rDNA genes [1,5], currently preventing a routine use in large-scale biodiversity studies. As a consequence, our study was focused on analysing the usefulness of three short expansion segments from two different rRNA genes (18S and 28S) as supplementary molecular markers to the COI barcode region for ground beetles. In contrast to COI, the species identification threshold for all analysed rDNA marker had an amount of one base substitution, insertion or deletion. The individual identification success using the rDNA marker was limited: The D3 marker was able to discriminate 61 (81\%) species, the V4 marker 57 (76\%), and the V7 marker allowed an unambiguous identification of 65 (87\%) species. However, the combination of all three nuclear markers provided resolution for 71 (95\%) species. Only two species pairs, Clivina collaris/fossor and Pterostichus nigrita/rhaeticus, were not discriminated (Figure 6, Table 1). Summarizing all results, our data showed that COI represented the most successful molecular marker for species determination $(73=97 \%)$ for the studied ground beetle species, closely followed by the combination of all three nuclear rDNA markers $(71=95 \%)$. 


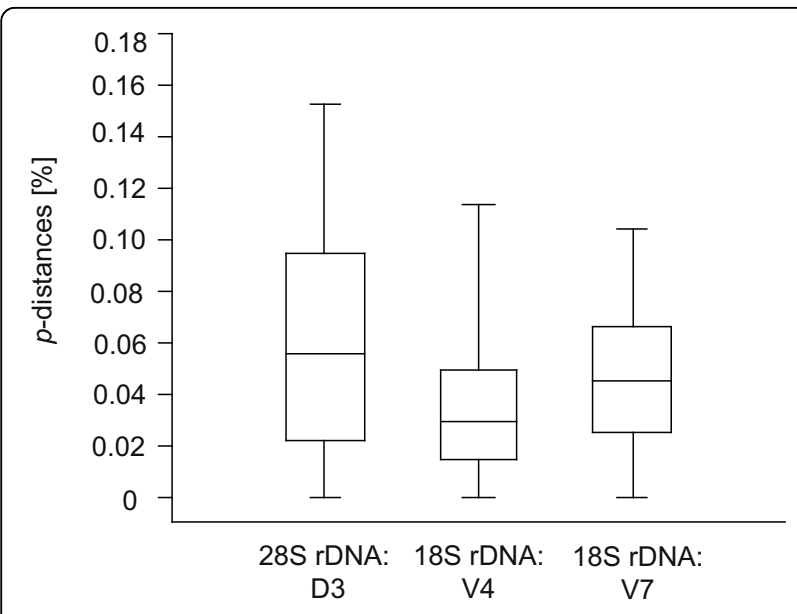

Figure 5 Boxplot distribution of the interspecific $p$-distances for the D3, V4 and V7 gene fragments. See Methods for methods of distance calculation and boxplot representations.

The analysed nuclear ribosomal expansion segments show some important aspects that are quite useful in molecular species identification. Firstly, they show a significant species level genetic variability and divergence for most species when used in combination; the exclusive use of a single segment will not discriminate all analysed species. Secondly, all analysed fragments have appropriately short sequence lengths in comparison to the COI fragment, facilitating easy amplification and sequencing. Finally, highly conserved flanking sites allow the generation of primers useable for a broad range of taxa. However, it must be emphasized that the power of rDNA sequences for identifying species is limited when sister species pairs have a very recent origin, as suggested for Clivina collaris and Clivina fossor. In such cases, the analysis of COI sequences represents a more advantageous and effective approach, because substitution rates of mitochondrial genes are, in general, higher than those of nuclear rRNA genes. Nevertheless, the quality of other expansion segments to discriminate species, especially closely related ones, should be also tested in further studies.

Our analysed data revealed some important insights into the genetic variability of nuclear genes and mitochondrial genes of ground beetles that are discussed in more detail.

\section{The sibling species pair Bembidion lampros/properans -} molecular data confirm two distinct species

Although overall morphological differences between both species are small, for example characteristic frontal furrows, the structure of the elytral striae and shape of the pronotum [98,102,112], both Bembidion species can be clearly distinguished by all molecular markers used.
Interspecific $\mathrm{K} 2 \mathrm{P}$ distances for $\mathrm{COI}$ ranged from 9 to 9.4\% ( $p$-distances: $8.4-8.8 \%$ ), while the number of sequence substitutions ranged from three (V4) to four (V7, D3) for the analysed nuclear markers. For all four markers, sequence divergence between both species lay considerably above any of the thresholds suggested in the literature or our own study, indicating that Bembidion lampros and Bembidion properans are in fact two distinct species.

\section{The sibling species Pterostichus nigrita/rhaeticus - speciation in progress?}

Various ecological and crossbreeding studies give evidence of two long ignored but distinct species, Pterostichus nigrita and Pterostichus rhaeticus [95-98,113]. Overall morphological differences between both species are very subtle and hardly noticeable. Males may be identified by the shape of the inflated endophallus including intermediate stages, while females can be identified by the form of the eighth abdominal sternite [96-98]. Accordingly, there were no sequence variations within the three nuclear markers and the COI sequence divergence (K2P distances: 0 to $0.01 \%, p$-distances: 0 to $0.01 \%$ ) was very low. For COI, both species shared identical haplotypes, and there was no evidence for any differentiation among both species (Figure 7). It was not possible to consistently discriminate between both species using any of the analysed molecular markers in this study. However, when species pairs have very recent origins or hybridize, the use of DNA sequences for species identification is very limited: after the initial "split", new sister species will share alleles and mutations in slowly evolving genes [114]. Beside this, morphological distinctiveness may evolve much faster than the studied popular "standard" genes. Further specimens from various locations and different markers should be tested to understand the population structure of this species complex in more detail. Molecular markers with a higher resolution on population level, for example microsatellites or SNPs rather than single locus coding genes alone can give more insights into genetic variability and gene flow through migration and dispersal $[10,11]$.

\section{Clivina collaris/fossor - recently evolved distinct species?}

The ground beetle Clivina collaris represents the sister species of Clivina fossor and has, in the past, often been regarded as a variety of the former [112]. However, Clivina collaris is somewhat smaller and flatter than Clivina fossor, and various other morphological traits (the shape of the elytra, genital morphology, details of the inner armature and different ecological preferences) clearly support the existence of two closely related but distinct species $[89,115]$. Kimura 2-parameter distances 


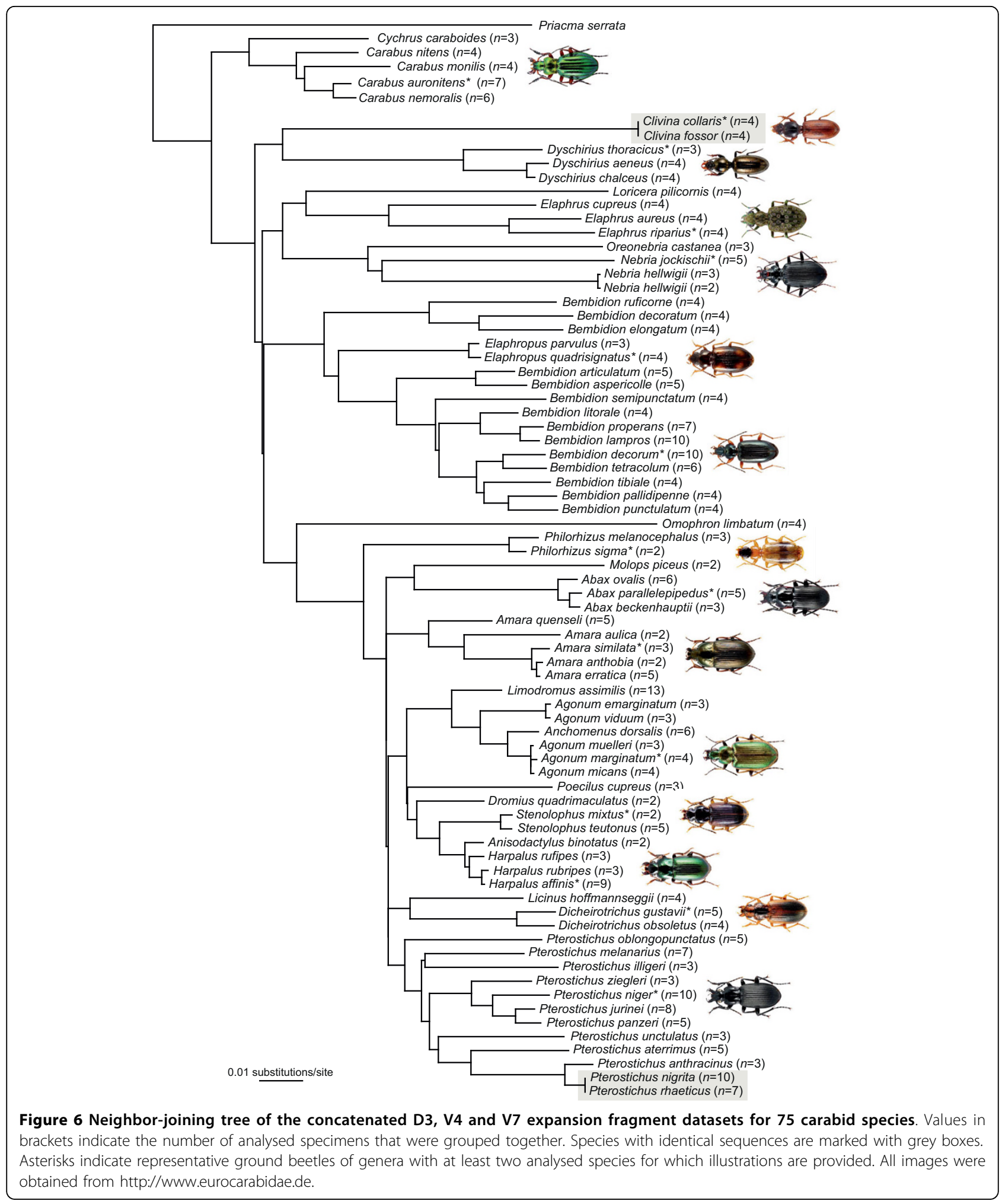

of the COI sequences ranged from 4.5 to $5.3 \%$ ( $p$-distance: 4.4-5.1\%), while all three nuclear datasets revealed no sequence variation, indicating a possible recent separation of both species.
Nebria hellwigii - more than one species?

The distribution of Nebria hellwigii is restricted to the alpine and high alpine regions of the Eastern Alps [89]. Based on genital morphology, a few subspecies are 


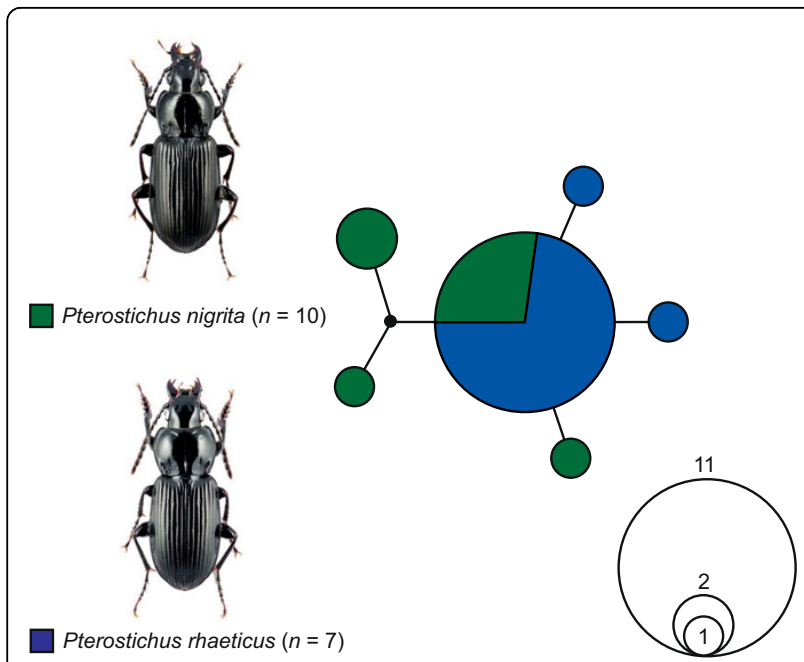

Figure 7 Statistical parsimony network showing the mutational relationships among the analysed mitochondrial $\mathrm{COI}$ haplotypes of Pterostichus nigrita (green) and Pterostichus rhaeticus (blue). Each line in the network represents a single mutational change; small black dots indicate missing haplotypes. The numbers of analysed specimens ( $n$ ) are listed; the diameter of the circles is proportional to the number of haplotypes sampled (see Open circles with numbers). Images were obtained from http:// www.eurocarabidae.de.

discussed [89]. Our data revealed two distinct COI haplotype lineages without intermediates and K2P distances of $3.8 \%$ ( $p$-distance: $3.7 \%$ ) that are higher than the lowest interspecific distances (K2P distances: $3.14 \%$, $p$-distances: $3.06 \%$, see above). However, both lineages were also identified by the nuclear V7 marker (Figure 6), giving evidence for the existence of a sibling species pair with sympatric distribution. Additional specimens have to be studied to evaluate these first results more in detail.

\section{Carabus nemoralis - indication of introgressive} hybridization events and/or incomplete lineage sorting

A European wide-temperate and highly eurytopic species, Carabus nemoralis is widely distributed throughout Central and Northern Europe [89]. Beside significant shape variations between different populations $[116,117]$, population genetic analyses using microsatellites revealed a complex genetic differentiation $[118,119]$. For this species, our COI data revealed two distinct haplotype lines with K2P distances of $2.7 \%$ ( $p$ distances: $2.6 \%$ ), without intermediates. However, all nuclear markers show no variation. Although we cannot exclude a linkage disequilibrium caused by inherited endosymbionts as well as heteroplasmy at the moment, introgressive hybridization events with other closely related Carabus species or incomplete lineage sorting represent the most plausible explanation for the observed high level of mitochondrial genetic differentiation. Both phenomena are well-known from other Carabus species and closely related genera [29-31,120]. In this case, the only use of COI sequences for molecular taxonomy using a threshold of $2 \%$ or below (see above) will clearly overestimate species diversity.

\section{Conclusions}

Based on the analyses of our various datasets, we have come to the conclusion that nuclear ribosomal expansion segments can constitute a valuable and efficient supplement for classical DNA barcoding studies based on mitochondrial COI sequences. While the individual identification success using the rDNA marker was limited, the combination of all three nuclear markers provided resolution for 71 (95\%) of the studied 75 ground beetle species. Using COI, 73 species (97\%) of the studied ground beetle species were accurately identified. Our study confirms the high potential of DNA sequence data for successful species identification of even closely related ground beetle species.

\section{Methods}

\section{DNA extraction, amplification and sequencing}

For our study, a total number of 344 specimens belonging to 75 different species out of 26 carabid genera were analysed (Additional file 4). All beetles were identified by one of the authors of this article $(\mathrm{KH})$. The characterization of intraspecific variation, introgression or other phenomena as well as the detection of cryptic species cannot be accomplished with only one individual per species; therefore at least two specimens per species and, if possible, specimens from different locations were analysed. The number of studied specimens per species ranged from a minimum of two to a maximum of 13, with four individuals per species on average (Additional file 5).

Genomic DNA samples were prepared from fresh beetles, beetles preserved in $96 \%$ ethanol or pinned museum specimens. Total genomic DNA was extracted from dissected legs of specimens or complete specimens using the QIAmp ${ }^{\odot}$ Tissue Kit (Qiagen $\mathrm{GmbH}$, Hilden), following the manufacturers extraction protocol. Specimens are deposited in the collection of the Zoologisches Forschungsmuseum Alexander Koenig (ZFMK), Bonn, Germany. In addition, all analysed DNA extracts are deposited in the DNA bank of the ZFMK as part of the DNA Bank Network (http://www.dnabank-network.org).

In total, 344 sequences were newly generated for this study for all analysed gene fragments. GenBank accession numbers, tissue voucher depositories and collection site are listed in Additional file 4. Three sequences of one outgroup taxon (the cupedid beetle Priacma serrata, COI: EU839762, 18S rDNA: EU797411, $28 \mathrm{~S}$ rDNA: 
EU797380) were obtained from GenBank. All 1356 amplification reactions were carried out on a Thermal Cycler GeneAmp ${ }^{\odot}$ PCR System 2700/2720 (Applied Biosystems, Darmstadt) in $20 \mu \mathrm{l}$ volume, containing $4 \mu \mathrm{l}$ QSolution, $2 \mu \mathrm{l} 10 \times$ Qiagen PCR buffer, $2 \mu \mathrm{l}$ dNTPs (2 $\mathrm{mmol} / \mu \mathrm{l}$ ), $0.1 \mu \mathrm{l}$ of each primer (both $50 \mathrm{pmol} / \mu \mathrm{l}$ ), $1 \mu \mathrm{l}$ of DNA template with an amount between 2 to $150 \mathrm{ng} /$ $\mu \mathrm{l}, 0.2 \mu \mathrm{l}$ Qiagen Taq polymerase $(5 \mathrm{U} / \mu \mathrm{l})$, and filled up to $20 \mu \mathrm{l}$ with sterile $\mathrm{H}_{2} \mathrm{O}$.

The PCR temperature profile for the mitochondrial COI fragment (approx. $650 \mathrm{bp}$ ) using the primers LCO1480 and HCO2198 [121] consisted of an initial denaturation at $94^{\circ} \mathrm{C}(5 \mathrm{~min})$, followed by 38 cycles at $94^{\circ} \mathrm{C}$ (denaturation, $45 \mathrm{~s}$ ), $48^{\circ} \mathrm{C}$ (annealing, $45 \mathrm{~s}$ ), $72^{\circ} \mathrm{C}$ (extension, $80 \mathrm{~s}$ ), and a final extension at $72^{\circ} \mathrm{C}(7 \mathrm{~min})$. Approximately $200 \mathrm{bp}$ of the D3 region was amplified with the forward primer $\mathrm{CD} 3 \mathrm{~F}$ and reverse primer CD3R, using a PCR protocol of $94^{\circ} \mathrm{C}$ for 5 min (initial denaturation), 32 cycles with $94^{\circ} \mathrm{C}$ denaturation for $45 \mathrm{~s}$, $52^{\circ} \mathrm{C}$ annealing for $45 \mathrm{~s}$, and $72^{\circ} \mathrm{C}$ extension for $80 \mathrm{~s}$, followed by a final $72^{\circ} \mathrm{C}$ extension for $7 \mathrm{~min}$. A 360-510 bp region of the $\mathrm{V} 4$ gene fragment was amplified with the primer pair CV4F and CV4R. The PCR temperature protocol was $94^{\circ} \mathrm{C}$ for 5 min (initial denaturation), 32 cycles with $94^{\circ} \mathrm{C}$ denaturation for $45 \mathrm{~s}, 66^{\circ} \mathrm{C}$ annealing for $45 \mathrm{~s}$, and $72^{\circ} \mathrm{C}$ extension for $2 \mathrm{~min}$, followed by a final $72^{\circ} \mathrm{C}$ extension for 8 min. Finally, a 400-500 base pair region of the $\mathrm{V} 7$ region of the $18 \mathrm{~S}$ rDNA was amplified using the forward primer CV7F and either the reverse primer CV7R, with the following PCR conditions: $94^{\circ} \mathrm{C}$ for $5 \mathrm{~min}$ (initial denaturation), 32 cycles with $94^{\circ} \mathrm{C}$ denaturation for $45 \mathrm{~s}, 68^{\circ} \mathrm{C}$ annealing for 45 $\mathrm{s}$, and $72^{\circ} \mathrm{C}$ extension for $2 \mathrm{~min}$, followed by $72^{\circ} \mathrm{C}$ extension for $8 \mathrm{~min}$. All primers used in amplification and sequencing for all four gene fragments as well as all used PCR temperature profiles are provided in Additional file 6.

Negative and positive controls were included with each round of reactions. Two $\mu$ l of amplified product were verified for size conformity by electrophoresis in a $1 \%$ agarose gel with ethidium bromide using commercial DNA size standards, while the remaining PCR product was purified with the QIAquick $^{\odot}$ PCR Purification Kit (Qiagen $\mathrm{GmbH}$, Hilden). Purified PCR products were cycle sequenced and sequenced in both directions at a contract sequencing facility (Macrogen, Seoul, Korea) on an ABI3730 XL automatic DNA sequencer, using the same primers as used in PCR. Trace files revealed no potential ambiguities indicated by multiple peaks in the sequences. Double stranded sequences were assembled with the SeqMan ${ }^{\text {tw }}$ II program (DNASTAR, Inc., Konstanz, Germany). BLAST searches were performed to confirm the identity of all new sequences [122]. All aligned COI sequences were translated to amino acid sequences to check for nuclear mitochondrial pseudogenes (numts) using BioEdit 7.0.9.0 [123].

\section{Data analysis}

All sequences of each marker were aligned using MUSCLE version 3.6 [124] with default settings, generating four individual datasets. To analyse the intra- and interspecific genetic variability of species, uncorrected pairwise distances ( $p$-distances) and Kimura 2-parameter (K2P) distances for the COI sequences, and $p$-distances for all rDNA marker were obtained using PAUP*4.0b10 [125]. Interspecific K2P distances of the COI data set were plotted as histogram (Figure 1), while $p$-distances of all rDNA data sets were visualized using box-andwhiskers-plots (Figure 5) [126], which represent the overall shape of the dataset. Boxes indicate mean, 25th and 75th percentile, while whiskers show 10th and 90th percentile, respectively. In contrast to protein-coding genes, the presence of multiple indels in alignments of ribosomal expansion regions makes accurate homology assessments across distantly related taxa difficult or even impossible. To accommodate this problem, all nuclear marker sequences of genera with at least two analysed species were aligned on genus level independent from all other taxa. Subsequently, sequence divergence calculations were carried out using PAUP*4.0b10 (Figure 5). Apart from this, the frequencies of the different lengths of the rDNA expansion fragment lengths were plotted as histogram (Figure 4). All boxplots and histograms were calculated using PAST version 1.94b [127]. We also generated a Klee diagram (Figure 3) based on indicator vector correlations for analyzing and displaying affinities of COI haplotypes [128,129]. Using this method, uncorrected COI haplotype sequences were transformed into digital indicator vectors using $M=1$ sequence/species, generating unique representations of each sequence in the chosen vector space $[128,129]$. A false-color map depicts correlations among the remaining sequences and the species indicator vectors. The succession of species for this approach is provided in Additional file 7.

Neighbor-joining cluster analyses [130] were employed for graphical representation of patterns of nucleotide divergences among the individual specimens of the COI dataset (Figure 2), for each single rDNA dataset (D3: Additional file 1; V4: Additional file 2; V7: Additional file 3), and for a combined dataset including all three nuclear markers (Figure 6), using PAUP*4.0b10. The neighbor-joining analysis of the COI data set was based on K2P distances. Due to the fact that expansion segments cannot be aligned unambiguously in many cases, only $p$-distances were used for all four rDNA marker topologies. Bootstrap support values were obtained by re-sampling and analyzing 10,000 replicates for the COI 
data set. All alignments can be obtained from the first author upon request. In addition, a statistical parsimony network was constructed for the COI data sets of Pterostichus nigrita and Pterostichus rhaeticus with TCS 1.21 [131], using default settings (Figure 7).

It should be kept in mind that a deep phylogenetic signal is not of central importance for molecular (alpha) taxonomy, as it has been pointed out by various authors [132-134]. Instead of this, DNA barcoding and molecular taxonomy focus on species delineation and identification.

\section{Additional material}

\section{Additional file 1: Neighbor-joining tree of D3 expansion fragments} for $\mathbf{7 5}$ carabid species. Numbers in brackets indicate the number of analysed specimens. Species with identical sequences are marked with grey boxes.

Additional file 2: Neighbor-joining tree of V4 expansion fragments for $\mathbf{7 5}$ carabid species. Numbers in brackets indicate the number of analysed specimens. Species with identical sequences are marked with grey boxes.

Additional file 3: Neighbor-joining tree of V7 expansion fragments for $\mathbf{7 5}$ carabid species. Numbers in brackets indicate the number of analysed specimens. Species with identical sequences are marked with grey boxes.

Additional file 4: Species identification, location of collection, and GenBank accession numbers of the analysed Carabidae. Country codes: GER (Germany): NRW (Nordrhein-Westfalen), NS (Niedersachsen), SH (Schleswig-Holstein), RP (Rheinland-Pfalz), S (Sachsen), SA (SachsenAnhalt); AU (Austria): K (Kärnten), SM (Steiermark), and TI (Tirol).

Additional file 5: Histogram of studied specimens per species. See Additional file 4 for more detailed information.

Additional file 6: Primers and PCR protocols used in this study Additional file 7: Order of species used for the Klee diagram of indicator vector correlations of $\mathrm{COI}$ sequences. The analysis is based on a Neighbor-joining (NJ) analysis using $p$-distances.

\section{Acknowledgements}

We would like to thank Christina Blume, Claudia Etzbauer and Birthe Thormann for their laboratory assistance. We thank Bernhard Misof and Thomas Wagner for donating specimens and Ortwin Bleich for the permission to use photos of carabid specimens from http://www. eurocarabidae.de. We are very grateful to Lawrence Sirovich and Yu Zhang for their help generating the Klee diagram. We thank Monique Wengler for useful comments on improving language and style. We would also like to thank two anonymous referees for their helpful and valuable amendments and comments. Michael J. Raupach was supported by a research grant from the German Science Foundation (DFG) to Johann-Wolfgang Wägele (INST $427 / 1-1)$

\section{Author details}

'Zoologisches Forschungsmuseum Alexander Koenig, Adenauerallee 160162, 53113 Bonn, Germany. ${ }^{2}$ Senckenberg am Meer, Deutsches Zentrum für Marine Biodiversitätsforschung, Südstrand 44, 26382 Wilhelmshaven, Germany. ${ }^{3}$ Dresdener Straße 6, 45731 Waltrop, Germany. ${ }^{4}$ The Rockefeller University, 1230 York Avenue, New York NY 10065, UK.

\section{Authors' contribution}

MJR designed and coordinated the study, carried out the molecular analyses and drafted the manuscript. JJA, MKP and JWW contributed to the interpretation of the molecular data. KH provided most specimens and identified all analysed ground beetles. MYS helped with the generation of the Klee diagram. JWW initiated and oversaw the project. All authors contributed to the writing of the manuscript and approved the final manuscript.

\section{Competing interests}

The authors declare that they have no competing interests.

Received: 8 March 2010 Accepted: 13 September 2010 Published: 13 September 2010

\section{References}

1. Floyd R, Abebe E, Papert A, Blaxter M: Molecular barcodes for soil nematode identification. Mol Ecol 2002, 11:839-850.

2. Monaghan MT, Balke M, Gregory TR, Vogler AP: DNA-based species delineation in tropical beetles using mitochondrial and nuclear markers. Philos T Roy Soc B 2005, 360:1925-1933.

3. Hajibabaei M, Singer GAC, Clare EL, Hebert PDN: Design and applicability of DNA arrays and DNA barcodes in biodiversity monitoring. BMC Biol 2007, 5:24

4. Miller KB, Alarie $Y$, Wolfe GW, Whiting MF: Association of insect life stages using DNA sequences: the larvae of Philodytes umbrinus (Motschulsky) (Coleoptera: Dytiscidae). Syst Entomol 2005, 30:499-509.

5. Caterino MS, Tishechkin AK: DNA identification and morphological description of the first confirmed larvae of Heteriinae (Coleoptera: Histeridae). Syst Entomol 2006, 31:405-418.

6. Tang RWK, Yau C, Ng WC: Identification of stomatopod larvae (Crustacea: Stomatopoda) from Hong Kong waters using DNA barcodes. Mol Ecol Res 2010, 10:439-448

7. Hebert PDN, Cywinska A, Ball SL, de Waard JR: Biological identifications through DNA barcodes. P Roy Soc Lond B Bio 2003, 270:313-321.

8. Pereira F, Carneiro J, Amorim A: Identification of species with DNA-based technology: current progress and challenges. Recent Pat DNA Gene Sea 2008, 2:187-200

9. Waugh J: DNA barcoding in animal species: progress, potential and pitfalls. BioEssays 2007, 29:188-197.

10. Ballard JWO, Whitlock MC: The incomplete natural history of mitochondria. Mol Ecol 2004, 13:729-744.

11. Ballard JWO, Rand DM: The population biology of mitochondrial DNA and its phylogenetic implications. Annu Rev Ecol Syst 2005, 36:621-642.

12. Birky CW Jr, Maruyama T, Fuerst PA: An approach to population and evolutionary genetic theory for genes in mitochondria and chloroplasts, and some results. Genetics 1983, 103:513-527.

13. Hebert PDN, Ratnasingham S, de Waard JR: Barcoding animal life: cytochrome $c$ oxidase subunit 1 divergences among closely related species. P Roy Soc Lond B Bio 2003, 270:596-S99.

14. Smith MA, Fisher BL, Hebert PDN: DNA barcoding for effective biodiversity assessment of a hyperdiverse arthropod group: the ants of Madagascar. Philos T Roy Soc B 2005, 360:1825-1834.

15. Clare EL, Lim BK, Engstrom MD, Eger JL, Hebert PDN: DNA barcoding of neotropical bats: species identification and discovery within Guyana. Mol Ecol Notes 2006, 7:184-190.

16. Costa FO, deWaard JR, Boutillier J, Ratnasingham S, Dooh RT, Hajibabaei M, Hebert PDN: Biological identifications through DNA barcodes: the case of the Crustacea. Can J Fish Aquat Sci 2007, 64:272-295.

17. Hubert $N$, Hanner R, Holm E, Mandrak NE, Taylor E, Burridge M, Watkinson D, Dumont P, Curry A, Bentzen P, Zhang J, April J, Bernatchez: Identifying Canadian freshwater fishes through DNA barcodes. PLOS ONE 2008, 3:e2490

18. Smith MA, Fisher BL: Invasion, DNA barcodes, and rapid biodiversity assessment using the ants of Mauritius. Front Zool 2009, 6:31.

19. Zhou X, Adamowicz SJ, Jacobus LM, DeWalt RE, Hebert PDN: Towards a comprehensive barcode library for arctic life - Ephemeroptera, Plecoptera, and Trichoptera of Churchill, Manitoba, Canada. Front Zool 2009, 6:30.

20. Hajibabaei M, Smith MA, Janzen DH, Rodriguez JJ, Whitfield JB, Hebert PDN A minimalist barcode can identify a specimen whose DNA is degraded. Mol Ecol Notes 2006, 6:959-964.

21. Meusnier I, Singer GAC, Landry JF, Hickey DA, Hebert PDN, Hajibabaei M: A universal DNA mini-barcode for biodiversity analysis. BMC Genomics 2008, 9:214. 
22. Meyer CP, Paulay G: DNA barcoding: error rates based on comprehensive sampling. PLoS Biology 2005, 3:e422.

23. Wiemers M, Fiedler K: Does the DNA barcoding gap exist? - a case study in blue butterflies (Lepidoptera: Lycaenidae). Front Zool 2007, 4:8.

24. Pamilo P, Viljakainen L, Vihavainen A: Exceptionally high density of NUMTs in the honeybee genome. Mol Biol Evol 2007, 24:1340-1346.

25. Song H, Buhay JE, Whiting MF, Crandall KA: Many species in one: DNA barcoding overestimates the number of species when nuclear mitochondrial pseudogenes are coamplified. P Natl Acad Sci USA 2008, 105:13486-13491.

26. Buhay JE: "COI-like" sequences are becoming problematic in molecular systematic and DNA barcoding studies. J Crustacean Biol 2009, 29:96-110.

27. Hazkani-Covo E, Zeller RM, Martin W: Molecular poltergeists: mitochondrial DNA copies (numts) in sequenced nuclear genomes. PLoS Genetics 2010, 6:e1000834.

28. Petit RJ, Excoffier L: Gene flow and species delimitation. Trends Ecol Evol 2009, 24:386-393.

29. Sota T, Ishikawa R, Ujiie M, Kusumoto F, Vogler AP: Extensive trans-species mitochondrial polymorphisms in the carabid beetles Carabus subgenus Ohomopterus cause by repeated introgressive hybridization. $\mathrm{Mol}$ Ecol 2001, 10:2833-2847.

30. Streiff $R$, Veyrier $R$, Audiot $P$, Meusnier $S$, Brouat $C$ : Introgression in natural populations of bioindicators: a case study of Carabus splendens and Carabus punctatoauratus. Mol Ecol 2005, 14:3775-3786.

31. Zhang $A B$, Sota $T$ : Nuclear gene sequences resolve species phylogeny and mitochondrial introgression in Leptocarabus beetles showing transspecies polymorphisms. Mol Phyl Evol 2007, 45:534-546.

32. Pauls SU, Theissinger K, Ujvarosi L, Balint M, Hasse P: Patterns of population structure in two closely related, partially sympatric caddisflies in Eastern Europe: historic introgression, limited dispersal, and cryptic diversity. J N Am Benthol Soc 2009, 28:517-536.

33. Cianchi R, Ungano A, Marini M, Bullini L: Differential patterns of hybridization and introgression between the swallowtails Papillo machaon and $P$. hospiton from Sardinia and Corsica islands (Lepidoptera, Papilionidae). Mol Ecol 2003, 12:1461-1471.

34. Paquin P, Hedin MC: The power and perils of "molecular taxonomy": a case study of eyeless and endangered Cicurina (Araneae: Dictynidae) from Texas caves. Mol Ecol 2004, 13:3239-3255.

35. Croucher PJP, Oxford GS, Searle JB: Mitochondrial differentiation, introgression and phylogeny of species in the Tegenaria atrica group (Araneae: Agelenidae). Biol J Linn Soc 2004, 81:79-89.

36. Kmiec B, Woloszynska M, Janska H: Heteroplasmy as a common state of mitochondrial genetic information in plants and animals. Curr Genet 2006, 50:149-159.

37. Parr RL, Maki J, Reguly B, Dakubo GD, Aguirre A, Wittock R, Robinson K Jakupciak JP, Thayer RE: The pseudo-mitoochondrial genome influences mistakes in heteroplasmy interpretation. BMC Genomics 2009, 7:185.

38. Dobson SL: Evolution of Wolbachia cytoplasmatic incompatibility types. Evolution 2004, 58:2156-2166.

39. Duron O, Bouchon D, Boutin S, Bellamy L, Zhou L, Engelstädter J, Hurst GD: The diversity of reproductive parasites among arthropods: Wolbachia do not walk alone. BMC Biol 2008, 6:27.

40. Jiggins FM, Hurst GDD, von der Schulenburg JHG, Majerus MEN: Two malekilling Wolbachia strains coexist within a population of the butterfly Acreae encedon. Heredity 2001, 86:161-166.

41. Hillis DM, Dixon MT: Ribosomal DNA: molecular evolution and phylogenetic inference. Q Rev Biol 1991, 66:411-453.

42. Hillis DM, Moritz C, Porter CA, Baker RJ: Evidence for biased gene conversion in concerted evolution of ribosomal DNA. Science 1991, 228:308-310.

43. Liao A: Concerted evolution: molecular mechanism and biological implications. Am J Hum Genet 1999, 64:24-30.

44. Eickbush TH, Eickbush DG: Finely orchestrated movements: evolution of the ribosomal RNA genes. Genetics 2007, 175:477-485.

45. Raupach MJ, Malyutina M, Brandt A, Wägele JW: Molecular data reveal a highly diverse species flock within the munnopsoid deep-sea isopod Betamorpha fusiformis (Barnard, 1920) (Crustacea: Isopoda: Asellota) in the Southern Ocean. Deep Sea Res Part II 2007, 54:1820-1830

46. Brökeland W, Raupach MJ: A species complex within the isopod genus Haploniscus (Crustacea: Malacostraca: Peracarida) from the Southern
Ocean deep sea: a morphological and molecular approach. $J$ Linn Soc London, Zool 2008, 152:655-706.

47. Faille A, Ribera I, Deharveng L, Bourdeau C, Garney L, Quéinnec E, Deuve T: A molecular phylogeny shows the single origin of the Pyrenean subterranean Trechini ground beetles (Coleoptera: Carabidae). Mol Phyl Evol 2010, 54:97-106.

48. Moore W: Phylogeny of the Western hemisphere Ozeanini (Coleoptera: Carabidae: Paussinae) based on DNA sequence data. Ann Carnegie Mus 2008, 77:79-92.

49. Maddison DR: Systematics of the North American beetle subgenus Pseudoperyphus (Coleoptera: Carabidae: Bembidion) based on morphological, chromosomal, and molecular data. Ann Carnegie Mus 2008, 77:147-193.

50. Ninet B, Jan I, Bontems O, Léchenne B, Jousson O, Panizzon R, Lew D, Monod M: Identification of Dermatophyte species by $28 \mathrm{~S}$ ribosomal DNA sequencing with a commercial kit. J Clin Microbiol 2003, 41:826-830.

51. Shirouzu T, Hirose D, Tokumasu S: Sequence analyses of the $28 \mathrm{~S}$ rRNA gene D1/D2 region suggest Dacrymyces (Heterobasidiomycetes, Dacrymycetales) is polyphyletic. Mycoscience 2007, 48:388-394.

52. McClain DK, Li J, Oliver JH Jr: Interspecific and geographical variation in the sequence of rDNA expansion segment D3 of Ixodes ticks (Acaria: Ixodidae). Heredity 2001, 86:234-242.

53. Monteiro FA, Wesson DA, Dotson EM, Schofield CJ, Beard CB: Phylogeny and molecular taxonomy of the Rhodniini derived from mitochondrial and nuclear DNA sequences. Am J Trop Med Hyg 2000, 62:460-465.

54. Markmann M, Tautz D: Reverse taxonomy: an approach towards determining the diversity of meiobenthic organisms based on ribosomal signature sequences. Philos T Roy Soc B 2005, 360:1917-1924.

55. Sonnenberg R, Nolte AW, Tautz D: An evaluation of LSU rDNA D1-D2 sequences for their use in species identification. Front Zool 2007, 4:6.

56. Valentini A, Pompanon F, Taberlet P: DNA barcoding for ecologists. Trends Ecol Evol 2008, 24:110-117.

57. Crease TJ, Lynch M: Ribosomal DNA variation in Daphnia pulex. Mol Biol Evol 1991, 8:620-640.

58. Crease TJ, Taylor D: The origin and evolution of variable-region helices in V4 and V7 of the small-subunit ribosomal RNA of branchiopod crustaceans. Mol Biol Evol 1998, 15:1430-1446.

59. McTaggart SJ, Crease TJ: Selection on the structural stability of a ribosomal RNA expansion segment in Daphnia obtusa. Mol Biol Evol 2005, 22:1309-1319.

60. Keller I, Veltsos P, Nichols RA: The frequency of rDNA variants within individuals provides evidence of population history and gene flow across a grasshopper hybrid zone. Evolution 2008, 62:833-844.

61. Xu J, Zhang Q, Xu X, Wang Z, Qi J: Intragenomic variability and pseudogenes of ribosomal DNA in stone flounder Kareius bicoloratus. Mol Phyl Evol 2009, 52:157-166.

62. Gonzalez I, Gorski J, Campen T, Dorney D, Erickson J, Sylvester J, Schmickel R: Variation among human $28 \mathrm{~S}$ ribosomal RNA genes. $P$ Natl Acad Sci USA 1985, 82:7666-7670.

63. Leffers $\mathrm{H}$, Anderson $\mathrm{A}$ : The sequence of $28 \mathrm{~S}$ ribosomal RNA varies within and between human cell lines. Nucleic Acids Res 1993, 21:1449-1455.

64. Santos SR, Kinzie RA, Sakal K, Coffroth MA: Molecular characterization of nuclear small subunit (18S)-rDNA pseudogenes in a symbiotic dinoflagellate (Symbiodinium, Dinophyta). J Eukaryot Microbiol 2003, 50:417-421.

65. Carranza S, Giribet G, Ribera C, Barguna Riutort M: Evidence that two types of $18 \mathrm{~S}$ rDNA coexist in the genome of Dugesia (Schmidtea) mediterranea (Platyhelminthes, Turbellaria, Tricladia). Mol Biol Evol 1996, 13:824-832.

66. Krieger J, Fuerst PA: Characterization of nuclear $18 \mathrm{~S}$ rRNA gene sequence diversity and expression in an individual lake sturgeon (Acipenser fulvescens). J Appl Ichthyol 2004, 20:433-439.

67. Krieger J, Hett AK, Fuerst PA, Birstein VJ, Ludwig A: Unusual intraindividual variation of the $18 \mathrm{~S}$ rRNA gene is widespread within the Acipenseridae. $J$ Hered 2006, 97:218-225.

68. Ali AB, Wuyts J, De Wachter R, Meyer A, van de Peer Y: Construction of a variability map for eukaryotic large subunit ribosomal RNA. Nucleic Acids Res 1999, 27:2825-2831.

69. Wuyts J, Van de Peer Y, De Wachter R: Distribution of substitution rates and location of insertions sites of tertiary structure of ribosomal RNA. Nucleic Acids Res 2001, 29:5017-5028. 
70. Hancock JM: The contribution of DNA slippage to eukaryotic nuclear $18 \mathrm{~S}$ rRNA evolution. J Mol Evol 1995, 40:629-639.

71. Hancock JM, Vogler AP: How slippage-derived sequences are incorporated into rRNA variable-region secondary structure: implications for phylogenetic reconstructions. Mol Phyl Evol 2000, 14:366-374.

72. Hwang UO, Ree HI, Kim W: Evolution of hypervariable regions, V4 and V7, of insect $18 \mathrm{~S}$ rRNA and their phylogenetic implications. Zool Sci 2000, 17:111-121.

73. Xie Q, Tian X, Qin Y, Bu W: Phylogenetic comparison of local length plasticity of the small subunit of nuclear rDNAs among all Hexapoda orders and the impact of hyperlength-variation on alignment. Mol Phyl Evol 2009, 50:310-316.

74. Gerbi SA: The evolution of eukaryotic ribosomal DNA. BioSystems 1986, 19:247-258.

75. Sweeney $R$, Chen $L$, Yao MC: An rRNA variable region has an evolutionarily conserved essential role despite sequence divergence. $\mathrm{Mol}$ Cell Biol 1994, 14:4203-4215.

76. van Nues RW, Venema J, Planta RJ, Raue HA: Variable region V1 of Saccharomyces cerevisiae $18 \mathrm{~S}$ rRNA participates in biogenesis and function of the small ribosomal subunit. Chromosoma 1997, 105:523-531.

77. Jeeninga RE, van Delft $Y$, de Graaff-Vincent M, Dirks-Mulder A, Venema J, Raue HA: Variable regions V13 and V3 of Saccharomyces cerevisiae contain structural features essential for normal biogenesis and stability of $5.8 \mathrm{~S}$ and 25S rRNA. RNA 1997, 3:476-488.

78. Spahn CM, Beckmann R, Eswar N, Penczek PA, Sali A, Blobel G, Frank J: Structure of the $80 \mathrm{~S}$ ribosome from Saccharomyces cerevisiae - tRNAribosome and subunit-subunit interactions. Cell 2001, 107:373-386.

79. Musters W, Boon K, van der Sande CA, van Heerikhuizen H, Planta RJ: Functional analysis of transcribed spacers of yeast ribosomal DNA. EMBO J 1990, 9:3989-3996.

80. Taylor DJ, Devkota B, Huang AD, Topf M, Narayanan E, Sali A, Harvey SC, Frank J: Comprehensive molecular structure of the eukaryotic ribosome. Structure 2009, 17:1591-1604.

81. Arnett RH, Thomas MC: American Beetles, Volume 1: Archostemata, Myxophaga, Adephaga, Polyphaga: Staphyliniformia Boca Raton, CRC Press LLC 2000.

82. Arndt E, Beutel RG, Will K: Carabidae Latreille, 1802. In Handbuch der Zoologie/Handbook of Zoology. Vol. IV Arthropoda: Insecta. Part 38. Coleoptera, Beetles. Vol 1: Morphology and Systematics (Archostemata, Adephaga, Myxophaga, Polyphaga partim). Edited by: Beutel RG, Leschen RAB. Berlin, W. deGruyter; 2005:119-146.

83. Lövei GL, Sunderland KD: Ecology and behaviour of ground beetles (Coleoptera: Carabidae). Annu Rev Entomol 1996, 41:231-256.

84. Maddison DR, Baker MD, Ober KA: Phylogeny of carabid beetles as inferred fom 18S ribosomal DNA (Coleoptera: Carabidae). Syst Entomol 1999, 24:103-138.

85. Ober KA: Phylogenetic relationships of the carabid subfamily Harpalinae (Coleoptera) based on molecular data. Mol Phyl Evol 2002, 24:228-248.

86. Pearce $J$, Venier LA: The use of ground beetles (Coleoptera: Carabidae) and spiders (Araneae) as bioindicators of sustainable forest management: A review. Ecol Indic 2006, 6:780-793.

87. Maddison DR: Systematics of the North American beetle subgenus Pseudoperyphus (Coleoptera: Carabidae: Bembidion) based on morphological, chromosomal, and molecular data. Ann Carnegie Mus 2008, 77:147-193.

88. Rainio J, Niemelä J: Ground beetles (Coleoptera: Carabidae) as bioindicators. Biodivers Conserv 2003, 12:487-506.

89. Müller-Motzfeld G, (Editor): Vol. 2 Adephaga 1: Carabidae (Laufkäfer). In Die Käfer Mitteleuropas. Edited by: Freude H, Harde KW, Lohse GA, Klausnitzer B. Heidelberg/Berlin, Spektrum-Verlag; 2004:

90. Reiter E: Fauna Germanica - Die Käfer des Deutschen Reiches, Band I Stuttgart, K.G. Lutz Verlag 1908.

91. Jeannel R: Coléoptères carabiques, 1. Fauna de France 1941, 39:1-571

92. Jeannel R: Coléoptères carabiques, 2. Fauna de France 1942, 40:573-1173.

93. Müller G: Bembidion lampros Hrbst. und B. properans Steph. - zwei Arten? Entomol Nach 1971, 15:119-124.

94. Desender K, Crappe D: Larval and adult morphology and biometry of two sibling species Bembidion lampros (Herbst) and Bembidion properans Stephens (Coleoptera, Carabidae). Biol Jaarb 1983, 51:36-54.

95. Koch D: Pterostichus nigrita, ein Komplex von Zwillingsarten. Entomol BI 1984, 79:141-152.
96. Müller-Motzfeld G, Hartmann M: Zur Trennung von Pterostichus rhaeticus HEER and P. nigrita PAYK. (Col., Carabidae). Entomol Nachr Ber 1985, 29:13-17.

97. Angus RB, Brown RE, Bryant L: Chromosomes and identification of the sibling species Pterostichus nigrita (Paykull) and $P$. rhaeticus Heer (Coleoptera: Carabidae). Syst Entomol 2000, 25:325-337.

98. Angus RB, Galián J, Wrase DW, Chaladze G: The western Palaearctic species of the Pterostichus nigrita (Paykull) complex, with the description of a new species from Spain and a new subspecies of $P$. nigrita from Anatolia (Coleoptera, Carabidae). Nouv Rev Entomol 2008, 25:297-316

99. Ferguson JWH: On the use of genetic divergence for identifying species. Biol J Linn Soc 2002, 75:509-516.

100. Hebert PDN, Stoekle M, Zemlak T, Francis CM: Identification of birds through DNA barcodes. PLoS Biology 2004, 2:1657-1668.

101. Hebert PDN, Penton EH, Burns JM, Janzen DH, Hallwachs W: Ten species in one: DNA barcoding reveals cryptic species in the neotropical skipper butterfly Astrapes fulgerator. P Natl Acad Sci USA 2004, 101:14812-14817.

102. Ball SL, Hebert PDN, Burian SK, Webb JM: Biological identifications of mayflies (Ephemeroptera) using DNA barcodes. J N Am Benthol Soc 2005, 24:508-524.

103. Ward RD, Zemlak TS, Innes BH, Last PR, Hebert PDN: DNA barcoding Australia's fish species. Philos T Roy Soc B 2005, 360:1847-1857.

104. Holmes BH, Steinke D, Ward RD: Identification of shark and ray fins using DNA barcoding. Fish Res 2009, 95:280-288.

105. Lefébure T, Douady CJ, Gouy M, Gibert J: Relationship between morphological taxonomy and molecular divergence within Crustacea: proposal of a molecular threshold to help species delimitation. Mol Phyl Evol 2006, 40:435-447.

106. Vences $M$, Thomas $M$, van der Meijden A, Chiari Y, Vietes DR: Comparative performance of the $16 \mathrm{~S}$ rRNA gene in DNA barcoding of amphibians. Front Zool 2005, 2:5.

107. Frézal L, Leblois R: Four years of DNA barcoding: current advances and prospects. Infect Genet Evol 2008, 8:727-736.

108. Pons J, Barraclough TG, Gomez-Zurita J, Cardoso A, Duran DP, Hazell S, Kamoun S, Sumlin WD, Vogler AP: Sequence-based species delimitation for the DNA taxonomy of undescribed insects. Syst Biol 2006, 55:595-609.

109. Papadopoulou A, Bergsten J, Fujisawa T, Monaghan MT, Barraclough TG, Vogler AP: Speciation and DNA barcodes: testing the effects of dispersal on the formation of discrete sequence clusters. Philos T Roy Soc B 2008, 363:2987-2996.

110. Monaghan MT, Wild R, Elliot M, Fujisawa T, Balke M, Inward DJG, Lees DC, Ranaivosolo R, Eggleton P, Barraclough TG, Vogler AP: Accelerated species inventory on Madagascar using coalescent-based models of species delineation. Syst Biol 2009, 58:298-311.

111. Papadopoulou A, Jones AG, Hammond PM, Vogler AP: DNA taxonomy and phylogeography of beetles of the Falkland Islands (Islas Malvinas). Mol Phy Evol 2009, 53:935-947.

112. Lindroth CH: The Carabidae (Coleoptera) of Fennoskandia and Denmark. Fauna Entomol Scan 1985, 15:1-232.

113. Thiele HU: Differences in measurement of day-length and photoperiodism in two stocks from subarctic and temperate climates in the carabid beetle Pterostichus nigrita F. Oeceologia 1977, 30:349-365.

114. Tautz D, Arctander P, Minelli A, Thomas RH, Vogler AP: A plea for DNA taxonomy. Trends Ecol Evol 2003, 18:70-74.

115. Sokolowski K: Clivina fossor L. 1758 und collaris Herbst. 1786 zwei distinkte Arten. Entomol B/ 1955, 51:81-84.

116. Brandl R, Topp W: Morphologische Variabilität von Carabus nemoralis (Col., Carabidae). Verh Deut Z 1983, 76:215.

117. Alibert $P$, Moureau B, Dommergues JL, David B: Differentiation at a microgeographical scale within two species of ground beetle, Carabus auronitens and C. nemoralis (Coleoptera, Carabidae): a geometrical morphometric approach. Zool Scr 2001, 30:299-311.

118. Brouat C, Sennedot F, Audiot P, Leblois R, Rasplus JY: Fine-scale genetic structure of two carabid species with contrasted levels of habitat specialization. Mol Ecol 2003, 12:1731-1745.

119. Brouat C, Chevallier H, Meusnier S, Noblecourt T, Rasplus JY: Specialization and habitat: spatial and environmental effects on abundance and genetic diversity of forest generalist and specialist Carabus species. Mol Ecol 2004, 13:1815-1826. 
120. Nagata N, Kubota K, Sota T: Phylogeography and introgressive hybridization of the ground beetle Carabus yamato in Japan based on mitochondrial gene sequences. Zool Sci 2007, 24:465-474.

121. Folmer O, Black M, Hoeh W, Lutz R, Vrijenhoek R: DNA primers for amplification of mitochondrial cytochrome $\mathrm{c}$ oxidase subunit I from diverse metazoan invertebrates. Mol Mar Biol Biotech 1994, 3:294-299.

122. Altschul SF, Madden TL, Schäffner AA, Zhang J, Zhang Z, Miller W, Lipman DJ: Gapped BLAST and PSI-BLAST: a new generation of protein database search programs. Nucleic Acids Res 1997, 25:3389-3402.

123. Hall TA: BioEdit: a user-friendly biological sequence alignment editor and analysis program for Windows 95/98/NT. Nucl Acid S 1999, 41:45-98.

124. Edgar RC: MUSCLE: a multiple sequence alignment method with reduced time and space complexity. BMC Bioinformatics 2004, 5:113.

125. Swofford DL: PAUP*: Phylogenetic analysis using parsimony (and other methods), version 4.0b10 Sunderland/Massachusetts, Sinauer Associates 2002.

126. Tuckey JW: Exploratory Data Analysis Boston, Addison-Wesley 1977.

127. Hammer $\varnothing$, Harper DAT, Ryan PD: PAST: Palaeontological statistics software package for education and data analysis. Palaeontol Electron 2001, 4:4.

128. Sirovich L, Stoeckle MY, Zhang Y: A scalable method for analysis and display of DNA sequences. PLOS ONE 2009, 4:e7051.

129. Sirovich L, Stoeckle MY, Zhang Y: Structural analysis of biodiversity. PloS ONE 2010, 5:e9266

130. Saitou N, Nei M: The neighbor-joining method: a new method for reconstructing phylogenetic trees. Mol Biol Evol 1987, 4:406-425.

131. Clement M, Posada D, Crandall KA: TCS: a computer program to estimate gene genealogies. Mol Ecol 2000, 9:1657-1660

132. Blaxter ML: The promise of a molecular taxonomy. Philos $T$ Roy Soc $B$ 2004, 359:669-679.

133. Steinke D, Salzburger W, Vences M, Meyer A: Taxl - A software tool for DNA barcoding using distance methods. Philos T Roy Soc B 2005, 360:1975-1980.

134. Astrin JJ, Huber BA, Misof B, Klütsch CFC: Molecular taxonomy in pholcid spiders (Pholcidae, Araneae): evaluation of species identification methods using CO1 and 16S rRNA. Zool Scr 2006, 35:441-457.

doi:10.1186/1742-9994-7-26

Cite this article as: Raupach et al: Molecular species identification of Central European ground beetles (Coleoptera: Carabidae) using nuclear rDNA expansion segments and DNA barcodes. Frontiers in Zoology 2010 7:26.

\section{Submit your next manuscript to BioMed Central and take full advantage of:}

- Convenient online submission

- Thorough peer review

- No space constraints or color figure charges

- Immediate publication on acceptance

- Inclusion in PubMed, CAS, Scopus and Google Scholar

- Research which is freely available for redistribution 